\title{
Assessment of River Bank Erosion and Vulnerability of Embankment to Breaching: A RS and GIS Based Study in Subansiri River in Assam, India
}

\author{
Ranjit Das ${ }^{*}$, Bipul Talukdar \\ Assam Engineering College, Gauhati University, India
}

Copyright $(2017$ by authors, all rights reserved. Authors agree that this article remains permanently open access under the terms of the Creative Commons Attribution License 4.0 International License

\begin{abstract}
Temporal Satellite Remote Sensing data of a river system of highly unstable bank can be analyzed in GIS environment for identification of river bank erosion as well as patches of embankment vulnerable to breaching. A case study was carried out in the Subansiri River, a tributary of river Brahmaputra of Assam, in India to identify locations of bank erosion and corresponding patches of embankment vulnerable to breaching. Temporal dataset of cartosat-1 imagery for the year 2007 and 2009 were used for mapping the flow channel of river Subansiri. Embankments present in the river were mapped from the cartosat- 1 data with the help of embankment index map collected from Assam State Water Resource Department. Based on the degree of convergence and narrowness between the flow channel and embankment, some patches of embankment identified as vulnerable to breaching and classified as very high, high and moderate vulnerable to breaching. Three patches of embankment were identified as very high vulnerable to breaching which came to be true in successive flood season of 2010. The method may be a good tool for predicting embankment vulnerability to breaching due to bank erosion and can be implemented for planning of river bank protection work and preparedness for flood season for a flood prone state like Assam.
\end{abstract}

Keywords RS and GIS, Bank Erosion, Embankment, Vulnerability

\section{Introduction}

Subansiri is one of the largest tributaries of river Brahmaputra [7]. It originates in the Himalaya, in China. Evidence indicate that the reach of Subansiri in the plain section represent one of the most dynamic and unstable alluvial rivers in the Brahmaputra valley [4]. 1210.2 Sq. km area gets inundated every year due to flood in Subansiri
River. To minimize these damages of this chronic flood, the river is confined by both side embankments since 1954 [7]. The silt which used to be deposited in the flood plain, now gets deposited inside the river channel leading to rising of river bed which again leads to increase the frequency of high flood. Floods of very high magnitude may be a contributing factor to channel widening and river bank erosion along with associated changes in the channel pattern [11 and 10]. The most common associated channel changes due to high flood are formation of sand bars, bank erosion, meandering etc.

Embankments are the structures constructed parallel to the river utilizing mostly the materials in situ. Due to the meandering nature of the river, the geometry between the flow channel of the river and the embankment does not remain parallel to each other. Higher the angle between these two, higher the thrust of water flow on the embankment resulting high probability of embankment breaching. Remote sensing (RS) satellite data have the ability to provide comprehensive, synoptic view of fairly large area at regular interval. Integration of Remote Sensing and Geographic Information System (GIS), make it appropriate and ideal for studying and monitoring of river bank erosion, changes of channel configuration and the orientations between the river channel and its embankments. Various studies in this regards have been carried out for some major rivers [3, 5, 12 and 13]. Several investigators have been used RS data for mapping and ascertaining the channel changes of different rivers in the world. Gogoi and Goswami [4] studied on channel migration of the Subansiri River using RS data. Bardhan M. [1] used RS and GIS technique and other data to identify relatively stable stretches of Barak River during the period 1910 to 1988. Space Application Centre (SAC) Ahmadabad in India and Brahmaputra Board Guwahati jointly studied to assess the extent of river erosion in Majuli Island in order to identify and delineate the areas of the island which have undergone changes along the bank line due to dynamic behavior of the river [9]. Naik et al. (1999) [6] studied the erosion at Kaziranga National Park in Assam using RS data. 


\subsection{Study Area}

The present study describes to identify stretches of embankment of Subansiri River vulnerable to breaching due to bank erosion and changes in channel. Cartosat-1 data for the year 2007, 2009 and 2010 was acquired and analyzed to map the channel configuration in the respective years. Using these data as input to GIS, the changes in the channel configurations like sand deposition, bank erosion, shifting of bank line and distance of the river channel to the embankment and their geometry was mapped and identified the vulnerable embankments. The river Subansiri is originated in China and flowing through Subansiri districts of Arunachal Pradesh and Lakhimpur District of Assam in India. Figure 1 showing the location map of the river system. This river causes flood in Lakhimpur District of Assam and concern authority constructed embankments for flood protection. Since embankment are present in Lakhimpur District of the river, the study confine in this portion only. Lakmipur District is located in eastern Assam and to the north bank of river Brahmaputra.

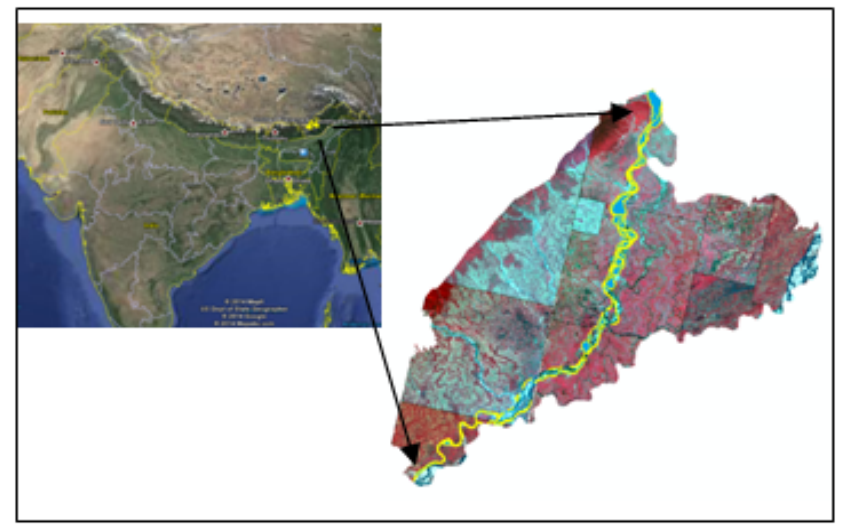

Figure 1. Study area

The basic data used in this study are digital satellite images of Indian Remote Sensing (IRS) P5 (Cartosat-1) (Row/Path 614/271, 614/272,614/273) sensor, comprising of scenes for the year 2007, 2009 and 2010. The other co-later data used in present study is embankment index map of Lakimpur district prepared by state Water Resources department of Assam.

\section{Methodology}

\subsection{Data analysis}

ERDASImagine image processing software has been used for processing the satellite images and Arc Map is utilized for mapping thematic layers. The geo coded cartosat-1 temporal dataset collected from NDC (NRSC Data Centre) were projected to UTM WGH 84 (zone 46) projection system and co-registered using ERDAS imagine software. The geo reference images of the same year have been mosaic together. Since Subansiri river covers by the images of same path of IRS P5 satellite, therefore the mosaic image is comprise of images of same data. The embankments are relatively permanent feature along the river. Since it is a linear feature associated with the water body (river) it appears uniquely in the panchromatic cartosat-1 images of $2.5 \mathrm{~m}$ resolution. The embankment index map for this district was referred while embankments were mapped from images. The channel configuration map was prepared using all the satellite image mosaic of 2007 and 2009. These two layers were combined in spatial analysis tools of Arc GIS to find out the changes areas. Places where the bank line has shifted outward the center line, it demarcated as erosion and the reverse is demarcated as deposition. The quantum of bank erosion was estimated in different locations of the channel.

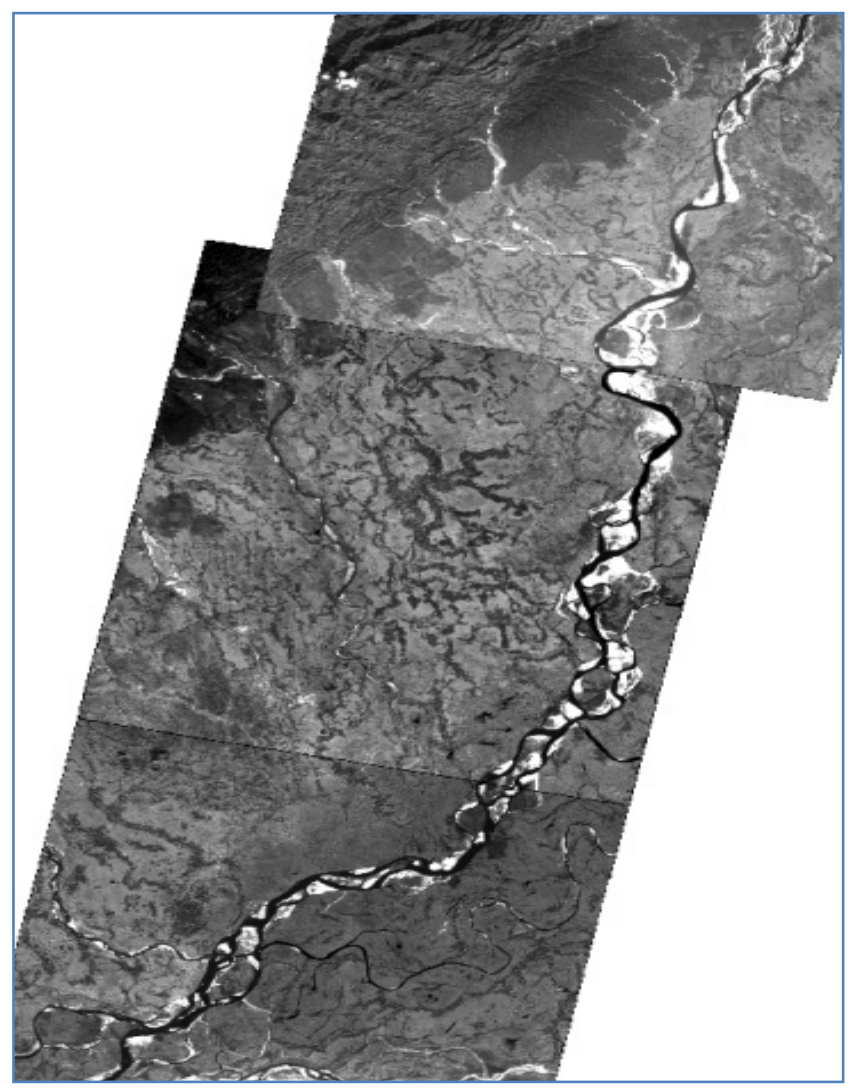

Figure 2. Cartosat-1 data for the year 2007

Looking at the quantum of bank erosion, angle between the embankment and channel flow and distance between them the stretches of embankment vulnerable to breach were identified. The vulnerability to breaching for the identified stretches of the embankment was verified with ground formations during the flood season for successive year 2010 and simultaneously it was verified with post flood satellite data. The geo rectified and co-registered cartosat- 1 imageries are shown in figure 2 and figure 3.

The embankments extracted from cartosat-1 images are as shown in figure 4 . The embankments are not continuous in the confluence points of sub tributaries of Subansiri. The 
right bank embankment is of $49.6 \mathrm{~km}$ length and the left bank embankment is $59 \mathrm{~km}$.

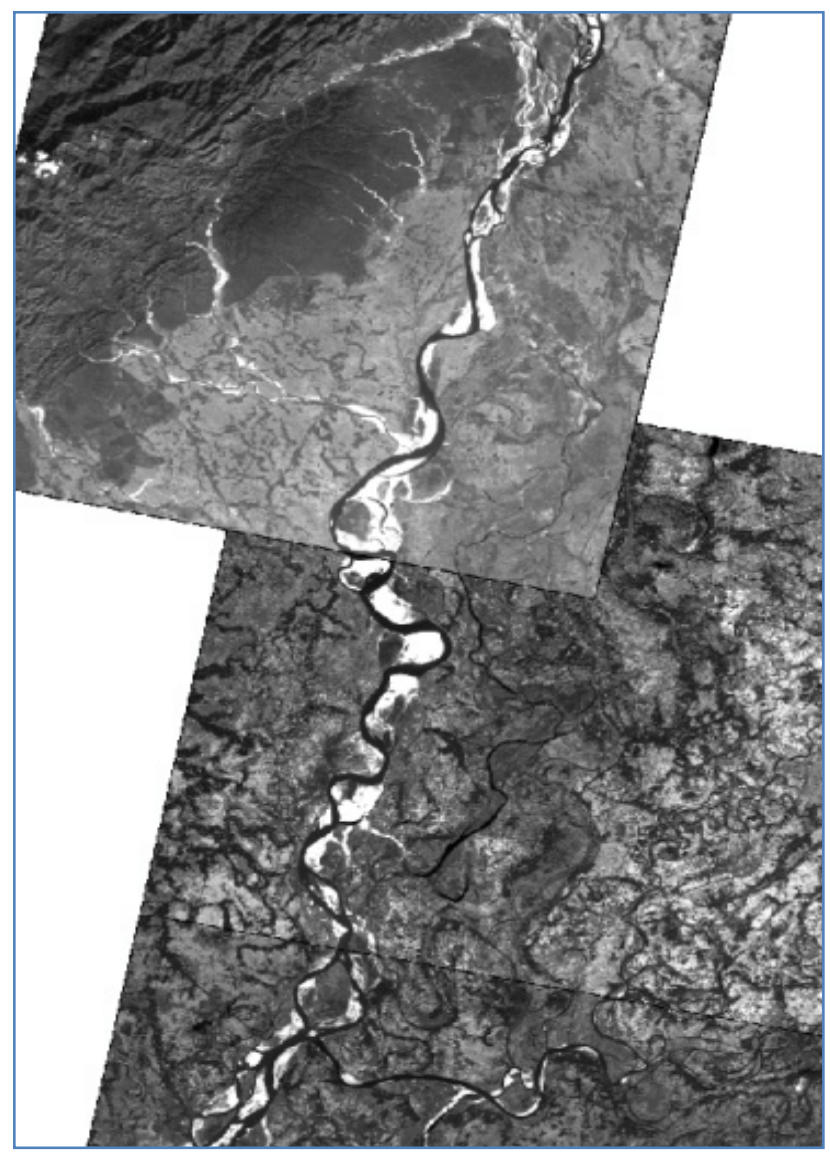

Figure 3. cartosat-1 data for the year 2009

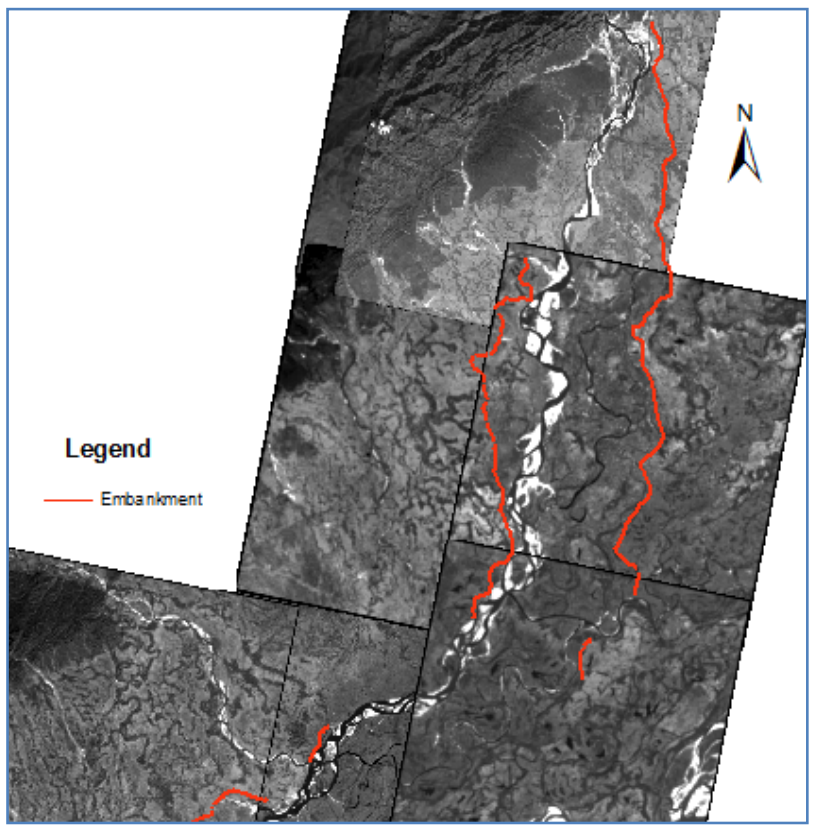

Figure 4. Embankments present in Subansiri River

The channel configuration map of Subansiri River for the year 2007 and the year 2009 is given in the figure 5 and figure 6 respectively

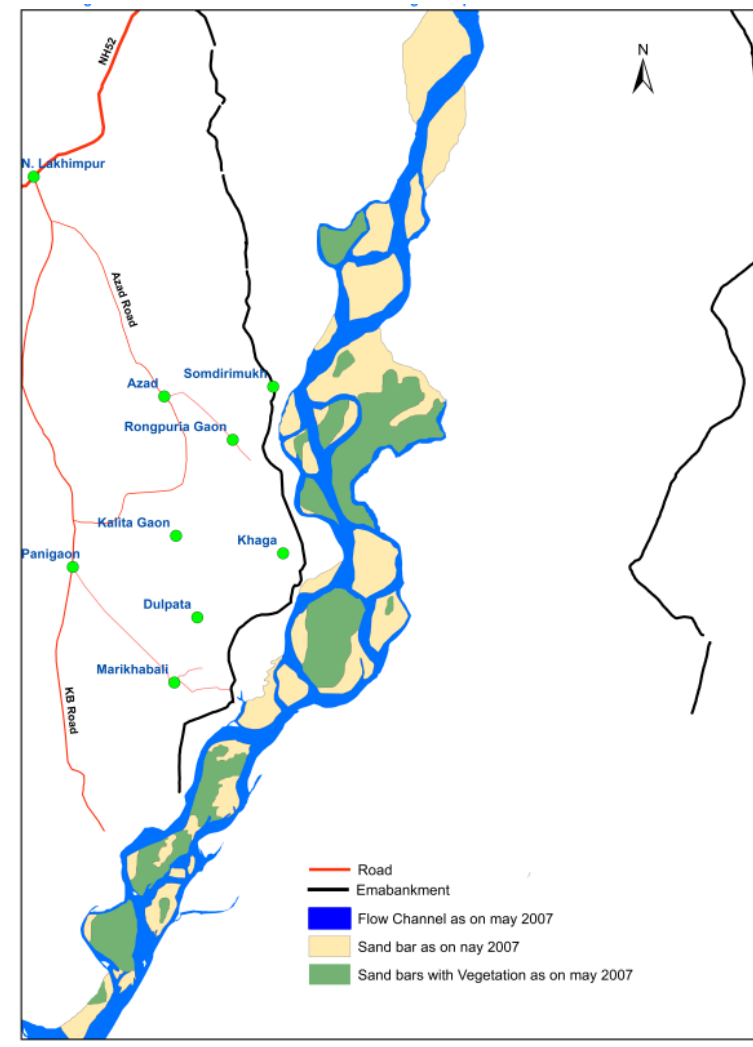

Figure 5. Channel configuration of Subansiri River in the year 2007

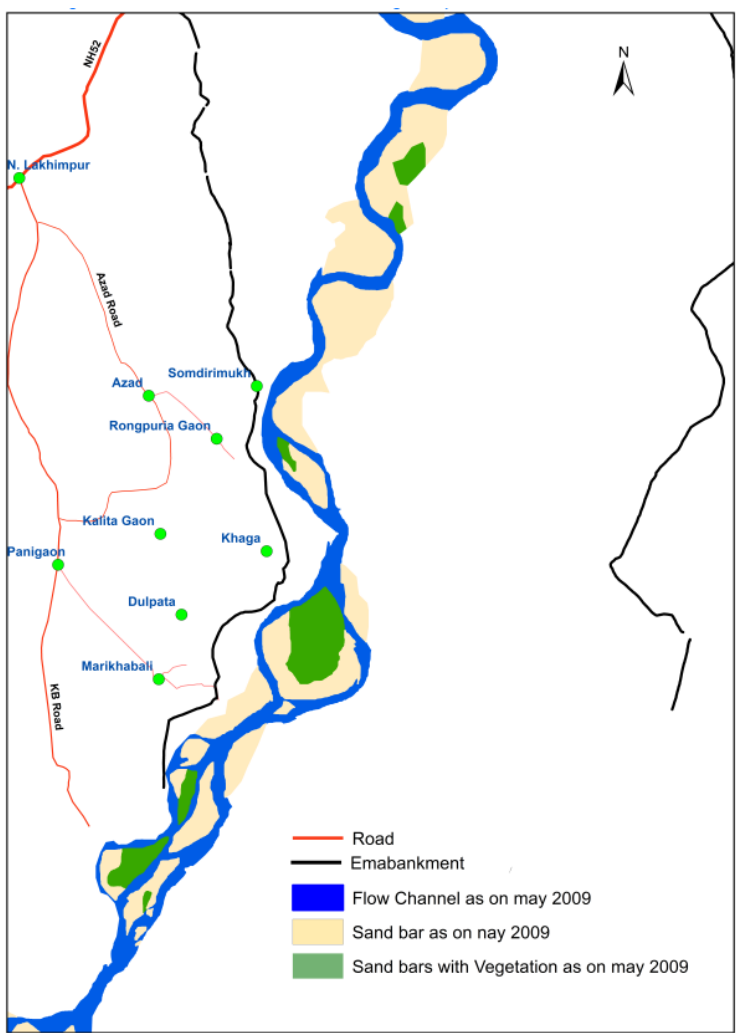

Figure 6. Channel configuration of Subansiri River in the year 2009 


\section{Results and Discussion}

The study shows that the river channel is quite dynamic. Lots of erosion and deposition occurs in the channel. As a hole the river bank shifted towards west during these two years 2007 to 2009. It has both braided and meandering nature. As a result of bank erosion and change in channel configuration, several stretches in the right bank embankment identified as vulnerable to breaching (figure 7).

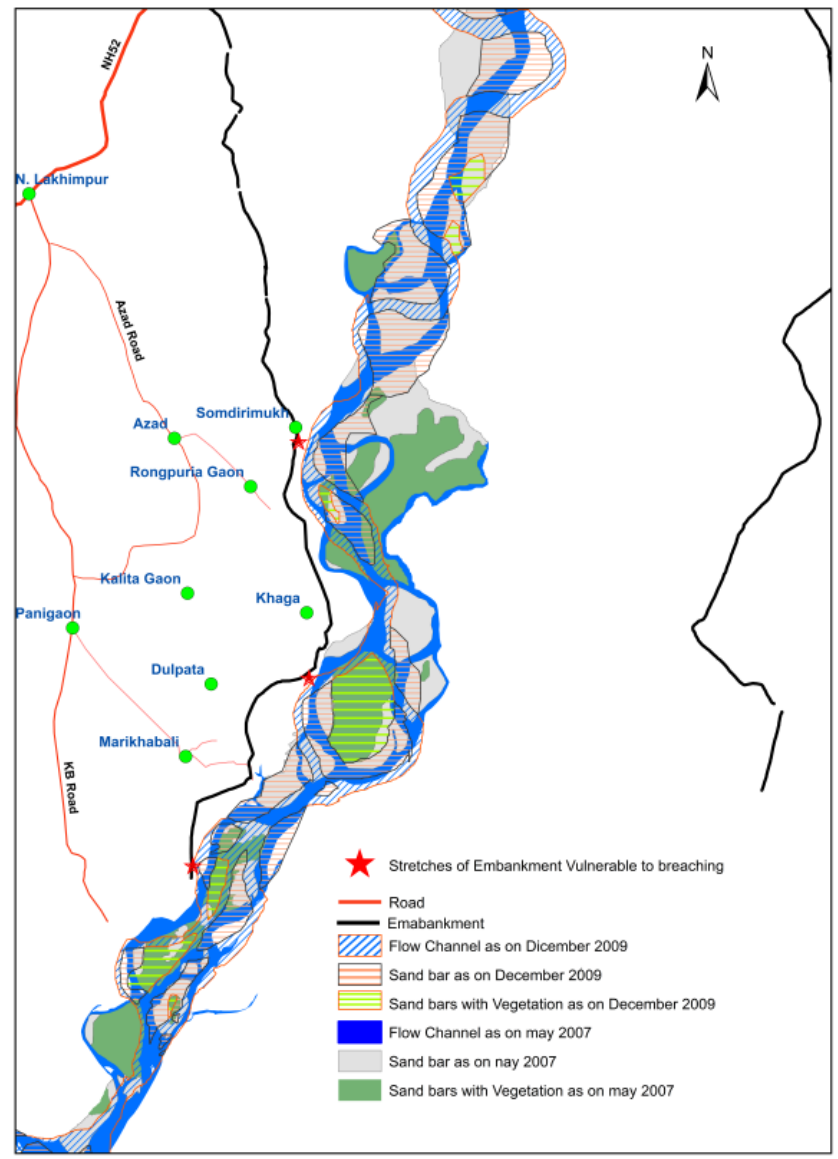

Figure 7. Changes in channel configuration of Subansiri River during the year 2007 to 2009

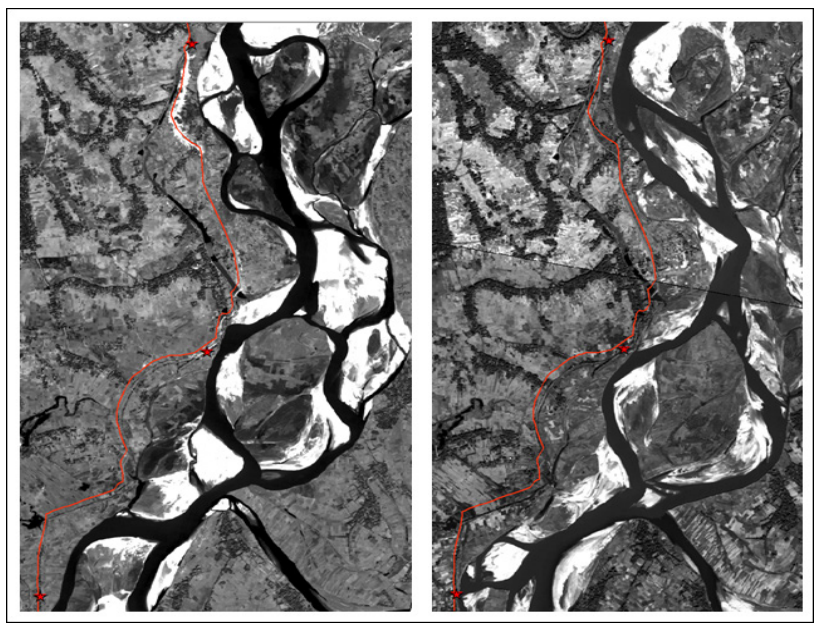

Figure 8. Changes of channel configuration of Subansiri River during 2007 to 2009 as viewed from cartosat-1

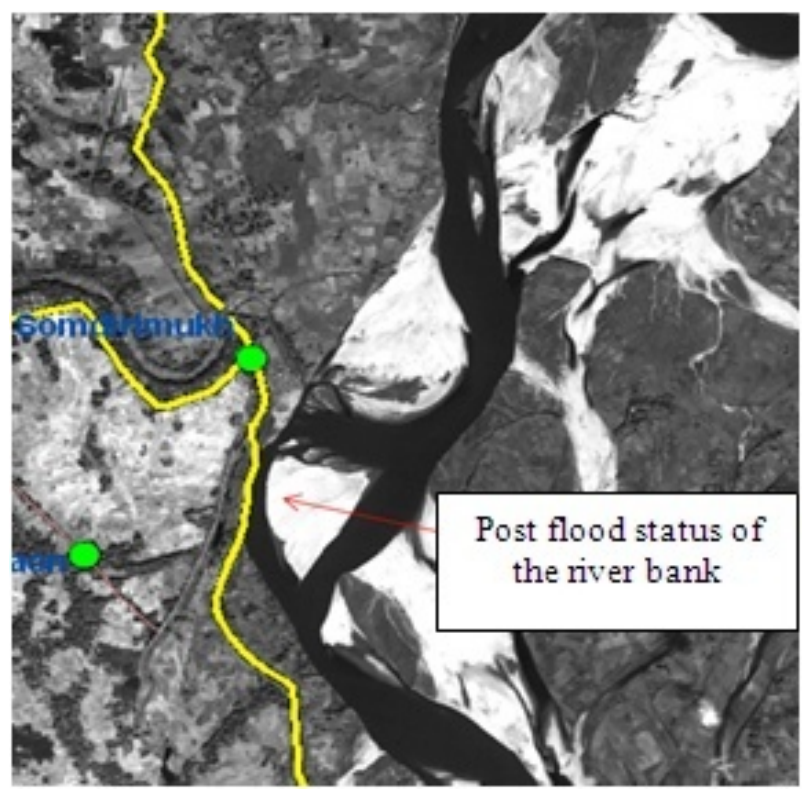

Figure 9. Bank erosion of Subansiri River after the flood event in 2010 near Sumdirimukh as viewed from cartosat-1

During the flood season of successive year 2010, the Water resources department had to take enormous river training work to prevent the embankment from breaching due to bank erosion. Cartosat-1 satellite image was analyzed to verify the bank erosion in the identified locations and showed evidence of bank erosion (figure 8).

\section{Summary and Conclusions}

A methodology has been developed which has successfully identified the changes in river configuration of the Subansiri river system of Assam, India. Erosion prone areas of the river stretch has been identified which are highly useful for planning of river bank protection work, river training work and preparedness for flood season of successive year for flood prone state like Assam.

\section{REFERENCES}

[1] Bardhan, M., 1993, Channel Stability of Barak River and its tributaries between Manipur - Assam and Assm Bangladesh Borders as seen from satellite imagery, Proceeding National Symposium on Remote Sensing application for Resource Management with Special emphasis on N. E. Region, Guwahati, 25-27 November 1993.

[2] Fuller I. C., Large A. R. G., and Milan D. J., 2003, Quantifying Channel development and Sediment Transfer Following chute Cute-off in a wandering Gravel-bed River, Geomorphology, 54(3-4), pp 307-323.

[3] Gogoi, C. and Goswami, D. C., 2014. A study on channel migration of the Subansiri River in Assam using Remote Sensing and GIS technology, Current Science, 106(8). 
[4] L. Q. Li. X. X. Luand Z, Chen, 2007, River channel change during the last 50 years in the middle Yantze River: An Example of Zianli Reach, Geomorphology, 85(3) pp. 185-196.

[5] Naik S. D., Chakravorty S. K., Bora T., and Hussain I., 1999, Errosion at Kaziranga National Park, Assam, A study based on Multi temporal satellite data, Project Report. Space Application Centre (ISRO) Ahmadabad and Brahmaputra Board, Guwahati p. 70

[6] Rao, K. L., 1979, India's Water health, Orient Blackswan, pp 78 ISBN 978-81-250-704-3

[7] Rinaldi M., (2003), "Recent Channel Adjustments in alluvial River of Tuscany, Central Italy", Earth Surface Processes and Landforms Vol. 28 No. 62003 pp, 587-608

[8] SAC and Brahmaputra Board, 1996, Report on Bank Erosion on Majuli Island, Assam: A Study based on Multi temporal
Satellite data, Space Application Centre, Ahmadabad and Brahmaputra Board, Guwahati.

[9] Schumm, S. A., 1968, River adjustment to altered hydrologic regimen - Murrumbidgee River and paleochannels Australia, U.S. Geol. Surv. Prof Pap., 1968 598, 65.

[10] Schumm, S. A., and Litchy, R. W., 1963, Channel widening and flood plain construction along Cimarron River in southwestern Kansas, U.S. Geol. Surv. Prof Pap., 1963352 D71-88

[11] Surian N., 1999, Channel Changes due to River Regulation: The Case of the Iave River, Italy, Earth Surface Processes and Landforms, 24(2), pp. 1135-1151.

[12] Yang X., Damen M.C. J., and Zuidam R. A. van., 1999, Satellite Remote Sensing and GIS for the analysis of Channel Migration Changes in the active yellow River Delta, China. International Journal of Applied Earth observation and Geo-information, 1(2), pp 145-157. 